DOI: https://doi.org/10.31933/dijdbm.v2i4 Received: $21^{\text {st }}$ may 2021, Revised: $10^{\text {th }}$ June 2021 , Publish: $11^{\text {st }}$ July 2021

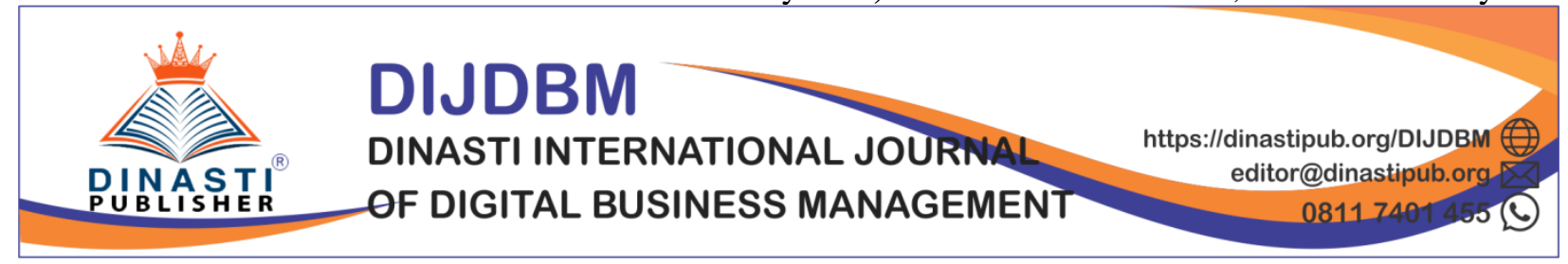

\title{
ANALYSIS OF CUSTOMER BEHAVIOR USING THE APRIORI METHOD
}

\author{
Renil Septiano' ${ }^{1}$, Sarjon Defit ${ }^{2}$, Laynita Sari $^{3}$ \\ 1) Sekolah Tinggi Ilmu Ekonomi KBP, West Sumatera, Indonesia, renil.septiano@gmail.com \\ 2) Putra Indonesia University YPTK Padang, West Sumatera, Indonesia, sarjond@yahoo.co.uk \\ 3) Sekolah Tinggi Ilmu Ekonomi KBP, West Sumatera, Indonesia, laynitasari4@gmail.com
}

\section{Corresponding Author: Renil Septiano ${ }^{1}$}

\begin{abstract}
Data is a very valuable asset because it is able to provide accurate, easy and fast information. This study processes coffee shop business data in the city of Padang to determine how customers behave in choosing menus. From the results of data processing. Researchers processed the data using the a priori method. From the results of data processing at a support value of $15 \%$, it is found that the majority of customers still buy menus in units.
\end{abstract}

Keywords: Apriori Algorithms, Customers, Data Mining.

\section{INTRODUCTION}

The fast flow of information due to technological developments also affects customer behavior. What is happening in any part of the world can easily be monitored for changes. These changes can be seen in the fields of fashion, culinary and even lifestyle. We can see how the clothes worn by world-class artists, in a short time have also become a trend in the country. In the culinary field, we can also see how a food or beverage menu that is trending abroad, quickly becomes a trend in our country, including lifestyle. We in Indonesia, who usually "hang out" in stalls with traditional drinks, have now also changed to follow trends that exist in the national and even international scope, namely non-hanging out in cafes.

With the proliferation of cafe businesses, it requires cafe owners to think creatively to create different concepts from other cafes. With the mushrooming of the cafe business, it will create an environment of competition between entrepreneurs with one another. With the increasingly fierce competition in the business world, especially in similar businesses, it makes companies move faster in terms of attracting customers. With this competition, the company applies the concept of marketing and observes customer behavior and looks for factors that influence purchasing decisions. Therefore companies need to know the wants and needs of customers and also the market. By understanding the needs, wants, and demands of customers, it provides important input for the company to design a good strategy in order to attract customers. 
"The presence of cafes, restaurants and other shopping centers is an indicator of West Sumatra's progress, especially in the city of Padang. This culinary business has an impact in helping the government to increase human resources and create jobs," said Mahyeldi, Monday, March 29, 2021. Governor West Sumatra also said that the existence of a café can be used as a venue for various organizational gathering events, even government activities (Joni Abdul Kasir, 2021).

One of the places known to many cafes is the seaside area of the city of Padang, West Sumatra Province or known as "taplau". Various types of food and drinks are sold at varying prices. From the range of cafes there, Aicon cafe is one of the cafes that sell drinks and food.

Aicon cafe is a business place that sells drinks and snacks. Aicon cafe only started operating in December 2020. Even though it is only operating compared to the entrepreneurs around it, Aicon cafe's sales have started to show improvement. To compete, of course Aicon cafe needs to know how its customers' habits are so that they can make further plans or strategies in marketing their products, as has been researched (Septiano \& Sari, 2020).

Researchers are interested in researching the behavior of customers who shop at Aicon cafe, especially drinks or foods that are customer favorites. The research was conducted by analyzing the sales data base of Aicon cafe. The sales data base is processed using the a priori method to produce knowledge, which will later be conveyed to the management or owner of Aicon cafe as an illustration by management or business owners in making sales strategies and further planning (Septiano, 2020).

Limitation of the Problem This research emphasizes to get a picture of customer purchasing patterns at a predetermined time. Purpose of Writing The purpose of this study is to produce knowledge from the data processing of customer purchases Aicon cafe.

\section{LITERATURE REVIEW}

\section{Data Mining}

Data Mining is an area that is in great demand and is used in various fields. Lately, this knowledge is needed by various groups. Students, lecturers, researchers and practitioners in the fields of management, meteorology, medicine, microbiology and many others use data mining techniques to help their work (Nofriansyah \& Defit, 2017). Data mining is a term used to describe the discovery of knowledge in computers. Data mining uses statistical data, mathematics, artificial intelligence, and machine learning to extract and identify useful information and related knowledge from large databases (Nofriansyah, 2014).

Data mining can spot hidden trends and patterns that don't show up in simple query analysis so it can have an important part in finding knowledge and making decisions. Such tasks can be predictive of such as classification and regression or descriptive such as clustering and association. Therefore, data mining actually has long roots in scientific fields such as artificial intelligence, mechanic learning, statistics and databases. Data mining needs to be studied and understood, because humans produce a lot of very large data (Wanto et al., 2020).

\section{Knowledge Discovery in Database (KDD)}

Knowledge Discovery in Database (KDD) is an activity that includes collecting, using, historical data to find regularities, patterns or relationships in large data sets (Siburian, 2014). 
Knowledge Discovery in Database (KDD) is defined as the extraction of potential, implicit and unknown information from a set of data. The Knowlegde Discovery in Database process involves the results of the data mining process (the process of extracting the tendency of a data pattern), then converting the results accurately into information that is easy to understand (Tampubolon et al., 2013).

The term Knowledge Discovery in Databases (KDD) refers to the entire process of seeking knowledge in large data sets. They classify data mining as one of the steps in the KDD process due to its application to a specific algorithm in looking for patterns (models) in the data (Azhari \& Anshori, 2015).

\section{Apriori}

Data mining is a process of obtaining useful information from a database warehouse in the form of knowledge. This study analyzes data using data mining and appriori algorithm methods. The priori algorithm is the most well-known algorithm for finding high frequency patterns. The a priori algorithm is divided into several stages called narration or pass Formation of an itemset candidate, a candidate is formed from a combination (k-1) -itemset obtained from the previous iterationowledge (Adha et al., 2017).

Apriori algorithm is easy to execute and very simple, is used to mine all frequent itemsets in database. The algorithm makes many searches in database to find frequent itemsets where kitemsets are used to generate k+1-itemsets. Each k-itemset must be greater than or equal to minimum support threshold to be frequency. Otherwise, it is called candidate itemsets. In the first, the algorithm scan database to find frequency of 1-itemsets that contains only one item by counting each item in database. The frequency of 1-itemsets is used to find the itemsets in 2itemsets which in turn is used to find 3-itemsets and so on until there are not any more kitemsets.

Apriori algorithm suffers from some weakness in spite of being clear and simple. The main limitation is costly wasting of time to hold a vast number of candidate sets with much frequent itemsets, low minimum support or large itemsets. For example, if there are 104 from frequent 1itemsets, it need to generate more than 107 candidates into 2-length which in turn they will be tested and accumulate. Furthermore, to detect frequent pattern in size 100 (e.g.) v1, v2 ... v100, it have to generate 2100 candidate itemsets that yield on costly and wasting of time of candidate generation. So, it will check for many sets from candidate itemsets, also it will scan database many times repeatedly for finding candidate itemsets. Apriori will be very low and inefficiency when memory capacity is limited with large number of transactions (Al-Maolegi \& Arkok, 2014).

\section{RESEARCH METHODS}

This research uses quantitative methods. The quantitative research method is one type of research whose specifications are systematic, well-planned and clearly structured from the start to the making of the research design (Sugiyono, 2017). (Sugiyono, 2019) defines population as a generalization area consisting of: objects / subjects that have certain qualities and characteristics determined by the researcher to study and then draw conclusions. The population of this study is all sales of Aicon cafe and for the sample is the sale of Aicon cafe in February 2021. 
Aicon cafe sales data is processed to obtain useful information using a priori algorithm using Microsoft Excel 2007 and the WEKA 3.8.5 application.

\section{FINDINGS AND DISCUSSION}

To process data in order to produce knowledge, it must be done in accordance with data mining procedures. The things that must be done are as follows:

\section{- Data Selection}

During February 2021, Aicon cafe had 556 transactions from February 1, 2021 to February 28, 2021. These transactions came from 46 menus at Aicon cafe which the author coded as follows:

Table 1. Aicon Cafe Menu List

\begin{tabular}{|c|c|c|}
\hline No & Item Code & Description \\
\hline 1 & A1 & Aiconic Beef BBQ \\
\hline 2 & $\mathrm{~A} 2$ & $\begin{array}{l}\text { Aiconic Beef } \\
\text { Blackpapper }\end{array}$ \\
\hline 3 & A3 & Aiconic Chicken BBQ \\
\hline 4 & A4 & Air Mineral \\
\hline 5 & A5 & Almond Latte \\
\hline 6 & A6 & Americano (Cold) \\
\hline 7 & A7 & Americano (Hot) \\
\hline 8 & A8 & Banana Latte \\
\hline 9 & A9 & Blue Ocean \\
\hline 10 & A10 & Cappucino (Cold) \\
\hline 11 & A11 & Cappucino (Hot) \\
\hline 12 & A12 & Caramel Macchiato \\
\hline 13 & A13 & Cheese Egg Mayo \\
\hline 14 & A14 & Chicken Original \\
\hline 15 & A15 & Choco Cheese Toast \\
\hline 16 & A16 & Chocolate \\
\hline 17 & A17 & Classic Caramel Toast \\
\hline 18 & A18 & Classic Choco Toast \\
\hline 19 & A19 & Espresso \\
\hline 20 & A 20 & Extra Ice Cream \\
\hline 21 & $\mathrm{~A} 21$ & Extra shot \\
\hline 22 & A22 & extra \\
\hline 23 & A23 & French Fries \\
\hline 24 & $\mathrm{~A} 24$ & Garlic Cheese Cream \\
\hline 25 & $\mathrm{~A} 25$ & Indomie Goreng Telor \\
\hline 26 & A26 & Indomie Rebus Telor \\
\hline 27 & $\mathrm{~A} 27$ & Kopi Susu Aicon \\
\hline 28 & A28 & Matcha Tea \\
\hline
\end{tabular}




\begin{tabular}{|l|l|l|}
\hline 29 & A29 & Milky Taro \\
\hline 30 & A30 & Pachoz \\
\hline 31 & A31 & Pisang Bakar Aicon \\
\hline 32 & A32 & Red Iced \\
\hline 33 & A33 & rice bowl beef \\
\hline 34 & A34 & rice bowl chiken \\
\hline 35 & A35 & rice bowl kulit \\
\hline 36 & A36 & Singkong \\
\hline 37 & A37 & snack aicon \\
\hline 38 & A38 & Thai Tea \\
\hline 39 & A39 & Tiramissu Latte \\
\hline 40 & A40 & tubruk \\
\hline 41 & A41 & V60 \\
\hline 42 & A42 & Vanilla Iced Toast \\
\hline 43 & A43 & Vanilla Latte \\
\hline 44 & A44 & Vanilla Rum Regal \\
\hline 45 & A45 & Vietnam Drip \\
\hline 46 & A46 & Virgin Mojito \\
\hline
\end{tabular}

\section{- Data Cleaning}

From 46 menu types and 556 transactions, then the data is converted into tables. Each menu (code A1-A46) where there is a transaction is assigned a number 1 in the table. Because the large amount of data does not allow for all to be displayed, the authors take part in the conversion results table like the following table:

Table 2. Menu Conversion Table

\begin{tabular}{|c|l|l|l|l|l|l|l|l|l|l|}
\hline Transaksi & A1 & A2 & A3 & A4 & A5 & A42 & A43 & A44 & A45 & A46 \\
\hline 1 & & & & & & & & & & \\
\hline 2 & & & & & & & 1 & & & \\
\hline 3 & & & & & & & & & 1 & \\
\hline 4 & & & & & & & & & & \\
\hline 5 & & & & & & & & & & \\
\hline 6 & & & & & & & & & & \\
\hline 7 & & & & & & & & & & \\
\hline 8 & & & & & & & 1 & & & \\
\hline 9 & & & & & & & 1 & & 1 & \\
\hline 10 & & & & & & & 1 & & & \\
\hline 550 & & & & & & & & & 1 & \\
\hline 551 & & 1 & & & & & & & & 1 \\
\hline 552 & & & & & & & & & & \\
\hline 553 & & & & & & & & & & \\
\hline 554 & & & & & & & & & & \\
\hline 555 & & & & & & & & & & \\
\hline 556 & & & & & & & & & & \\
\hline
\end{tabular}

\section{- Data Transforming}


At this stage, the data that is ready to be processed is transformed into a Comma Separated Values (CSV) file so that it can then be processed using software.tahap ini, application.

\section{- Data Mining}

At the data mining stage, the data is processed using the Apriori Algorithm method. The results of data processing produce the following support values:

Table 3. Support Value From Each Menu

\begin{tabular}{|c|c|c|c|}
\hline No & Item Code & Description & Support \\
\hline 1 & $\mathrm{~A} 1$ & Aiconic Beef BBQ & $0,7 \%$ \\
\hline 2 & $\mathrm{~A} 2$ & Aiconic Beef Blackpapper & $0,2 \%$ \\
\hline 3 & A3 & Aiconic Chicken BBQ & $0,5 \%$ \\
\hline 4 & A4 & Air Mineral & $7,7 \%$ \\
\hline 5 & A5 & Almond Latte & $3,8 \%$ \\
\hline 6 & A6 & Americano (Cold) & $5,0 \%$ \\
\hline 7 & A7 & Americano (Hot) & $1,1 \%$ \\
\hline 8 & A8 & Banana Latte & $0,5 \%$ \\
\hline 9 & A9 & Blue Ocean & $4,7 \%$ \\
\hline 10 & $\mathrm{~A} 10$ & Cappucino (Cold) & $7,6 \%$ \\
\hline 11 & A11 & Cappucino (Hot) & $0,5 \%$ \\
\hline 12 & A12 & Caramel Macchiato & $7,7 \%$ \\
\hline 13 & A13 & Cheese Egg Mayo & $3,1 \%$ \\
\hline 14 & A14 & Chicken Original & $1,6 \%$ \\
\hline 15 & A15 & Choco Cheese Toast & $1,3 \%$ \\
\hline 16 & A16 & Chocolate & $20,3 \%$ \\
\hline 17 & A17 & Classic Caramel Toast & $0,7 \%$ \\
\hline 18 & A18 & Classic Choco Toast & $1,1 \%$ \\
\hline 19 & A19 & Espresso & $2,7 \%$ \\
\hline 20 & A20 & Extra Ice Cream & $1,3 \%$ \\
\hline 21 & $\mathrm{~A} 21$ & Extra shot & $0,2 \%$ \\
\hline 22 & $\mathrm{~A} 22$ & extra & $0,2 \%$ \\
\hline 23 & A23 & French Fries & $19,8 \%$ \\
\hline 24 & A24 & Garlic Cheese Cream & $1,4 \%$ \\
\hline 25 & $\mathrm{~A} 25$ & Indomie Goreng Telor & $8,1 \%$ \\
\hline 26 & A26 & Indomie Rebus Telor & $4,0 \%$ \\
\hline 27 & A27 & Kopi Susu Aicon & $18,2 \%$ \\
\hline 28 & $\mathrm{~A} 28$ & Matcha Tea & $17,6 \%$ \\
\hline 29 & A29 & Milky Taro & $15,8 \%$ \\
\hline 30 & $\mathrm{~A} 30$ & Pachoz & $2,9 \%$ \\
\hline 31 & A31 & Pisang Bakar Aicon & $3,6 \%$ \\
\hline 32 & A32 & Red Iced & $15,1 \%$ \\
\hline
\end{tabular}




\begin{tabular}{|r|l|l|r|}
\hline 33 & A33 & rice bowl beef & $0,7 \%$ \\
\hline 34 & A34 & rice bowl chiken & $2,9 \%$ \\
\hline 35 & A35 & rice bowl kulit & $1,6 \%$ \\
\hline 36 & A36 & Singkong & $2,7 \%$ \\
\hline 37 & A37 & snack aicon & $7,2 \%$ \\
\hline 38 & A38 & Thai Tea & $11,2 \%$ \\
\hline 39 & A39 & Tiramissu Latte & $7,9 \%$ \\
\hline 40 & A40 & tubruk & $0,4 \%$ \\
\hline 41 & A41 & V60 & $2,5 \%$ \\
\hline 42 & A42 & Vanilla Iced Toast & $1,4 \%$ \\
\hline 43 & A43 & Vanilla Latte & $17,8 \%$ \\
\hline 44 & A44 & Vanilla Rum Regal & $0,2 \%$ \\
\hline 45 & A45 & Vietnam Drip & $4,5 \%$ \\
\hline 46 & A46 & Virgin Mojito & $4,0 \%$ \\
\hline
\end{tabular}

From discussions with the owner of Aicon Coffee and Toast, the minimum support was set at $15 \%$, so the following results were obtained:

Table 4. Menu that meet support

\begin{tabular}{|c|c|l|r|}
\hline No & Item Code & \multicolumn{1}{c|}{ Description } & Support \\
\hline 1 & A16 & Chocolate & $20,3 \%$ \\
\hline 2 & A23 & French Fries & $19,8 \%$ \\
\hline 3 & A27 & Kopi Susu Aicon & $18,2 \%$ \\
\hline 4 & A28 & Matcha Tea & $17,6 \%$ \\
\hline 5 & A29 & Milky Taro & $15,8 \%$ \\
\hline 6 & A32 & Red Iced & $15,1 \%$ \\
\hline 7 & A43 & Vanilla Latte & $17,8 \%$ \\
\hline
\end{tabular}

Furthermore, the process of forming $\mathrm{C} 2$ with 2 itemset, using minimum support $=15 \%$ (A, B) $=$ P (A B) Support (A, B).

Table 5. Formation of 2 Itemset

\begin{tabular}{|c|c|c|}
\hline Item Code & Amount & Support (\%) \\
\hline $\mathrm{A} 16-\mathrm{A} 23$ & 22 & $4,0 \%$ \\
\hline $\mathrm{A} 16-\mathrm{A} 27$ & 9 & $1,6 \%$ \\
\hline $\mathrm{A} 16-\mathrm{A} 28$ & 21 & $3,8 \%$ \\
\hline $\mathrm{A} 16-\mathrm{A} 29$ & 20 & $3,6 \%$ \\
\hline $\mathrm{A} 16-\mathrm{A} 32$ & 22 & $4,0 \%$ \\
\hline $\mathrm{A} 16-\mathrm{A} 43$ & 17 & $3,1 \%$ \\
\hline $\mathrm{A} 23-\mathrm{A} 27$ & 19 & $3,4 \%$ \\
\hline $\mathrm{A} 23-\mathrm{A} 28$ & 25 & $4,5 \%$ \\
\hline
\end{tabular}




\begin{tabular}{|c|c|c|}
\hline $\mathrm{A} 23-\mathrm{A} 29$ & 18 & $3,2 \%$ \\
\hline $\mathrm{A} 23-\mathrm{A} 32$ & 14 & $2,5 \%$ \\
\hline $\mathrm{A} 23-\mathrm{A} 43$ & 22 & $4,0 \%$ \\
\hline $\mathrm{A} 27-\mathrm{A} 28$ & 10 & $1,8 \%$ \\
\hline $\mathrm{A} 27-\mathrm{A} 29$ & 10 & $1,8 \%$ \\
\hline $\mathrm{A} 27-\mathrm{A} 32$ & 9 & $1,6 \%$ \\
\hline $\mathrm{A} 27-\mathrm{A} 43$ & 17 & $3,1 \%$ \\
\hline $\mathrm{A} 28-\mathrm{A} 29$ & 20 & $3,6 \%$ \\
\hline $\mathrm{A} 28-32$ & 14 & $2,5 \%$ \\
\hline $\mathrm{A} 28-43$ & 8 & $1,4 \%$ \\
\hline $\mathrm{A} 29-\mathrm{A} 32$ & 20 & $3,6 \%$ \\
\hline $\mathrm{A} 29-\mathrm{A} 43$ & 14 & $2,5 \%$ \\
\hline $\mathrm{A} 32-\mathrm{A} 43$ & 8 & $1,4 \%$ \\
\hline
\end{tabular}

In the formation of 2 itemsets, there were no combinations that met the criteria> $15 \%$. To provide a broader picture, then a support analysis was carried out by forming 3 itemsets with the following results:

Table 6. Menu that meets the 3 itemset criteria

\begin{tabular}{|l|r|r|}
\hline \multicolumn{1}{|c|}{ Item Code } & Amount & Suppot (\%) \\
\hline A16-A23-28 & 6 & $1,1 \%$ \\
\hline A16-A23-29 & 4 & $0,7 \%$ \\
\hline A16-A23-32 & 5 & $0,9 \%$ \\
\hline A16-A23-43 & 5 & $0,9 \%$ \\
\hline A23-A27-A28 & 4 & $0,7 \%$ \\
\hline A23-A27-A29 & 4 & $0,7 \%$ \\
\hline A23-A27-A32 & 4 & $0,7 \%$ \\
\hline A23-A27-A43 & 4 & $0,7 \%$ \\
\hline A27-A28-A29 & 1 & $0,2 \%$ \\
\hline A27-A28-A43 & 1 & $0,2 \%$ \\
\hline A28-A29-A32 & 4 & $0,7 \%$ \\
\hline A28-A29-A43 & 2 & $0,4 \%$ \\
\hline
\end{tabular}

From the table above, namely the formation with 3 itemset, again there was no support above $15 \%$.

To see the results of data processing using WEKA software, it can be seen from the following picture: 


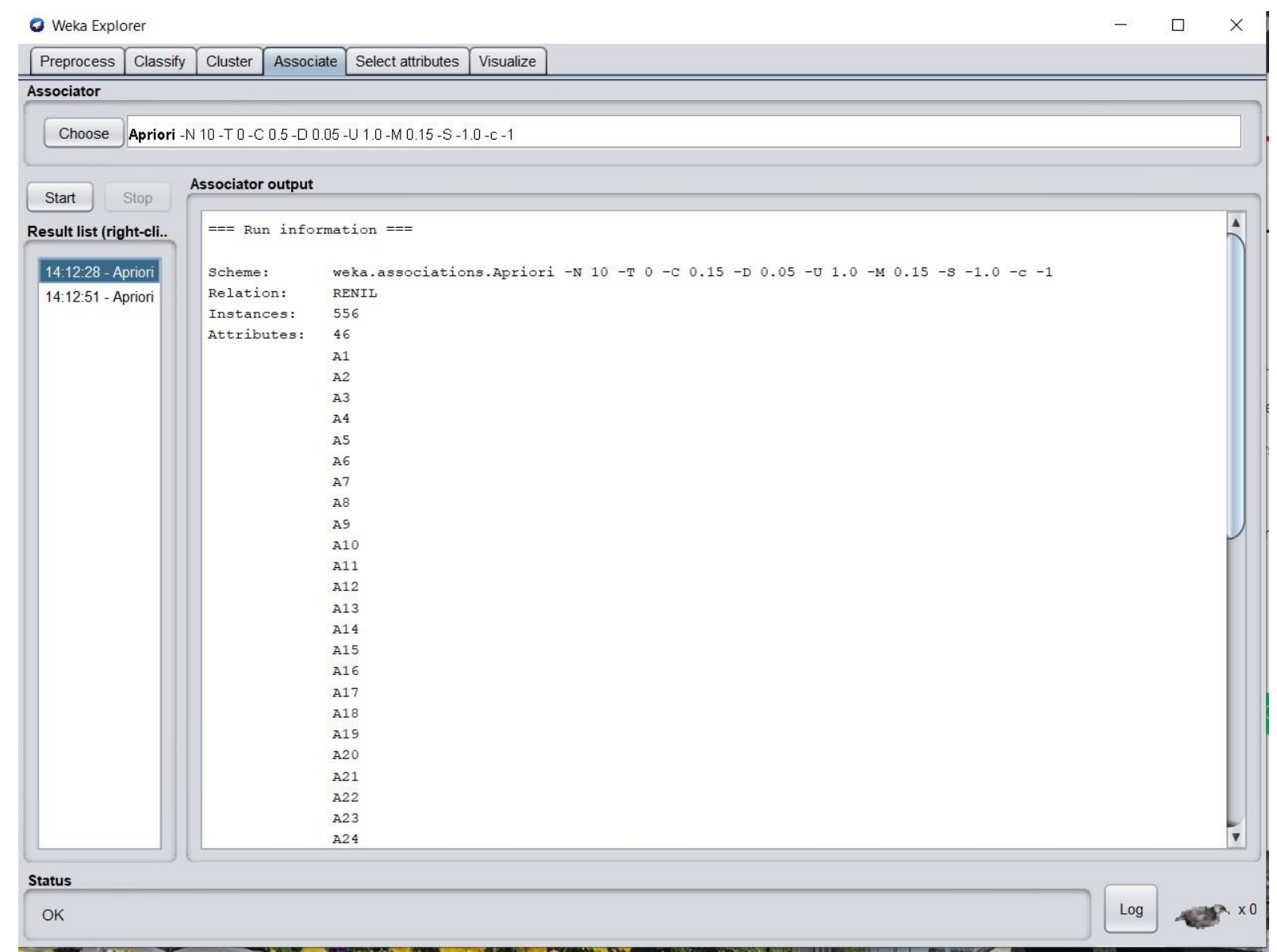

Picture 1. Results of data processing using the WEKA application

\section{CONCLUSION AND RECOMMENDATION}

- For data processing with a support value> 15\%, 7 menus were found that were categorized as: Chocolate, French Fries, Aicon Milk Coffee, Matcha Tea, Milky Taro, Red Iced, Vanilla Latte.

- For further data processing with 2 itemset and 3 itemset, there are no criteria that meet the requirements $>15 \%$

- It can be concluded, that for the support value> 15\%, that no Aicon Coffee \& Toast customers make purchases of more than one menu.

- Aicon Coffee \& Toast customers buy more unit menus because the majority of customers are students.

- Aicon cafe must be more active to offer other menus to customers who only buy 1 menu.

- The next researcher can conduct research with a longer sample period (more than 1 month) or can conduct research in other objects.

\section{BIBLIOGRAPHY}

Adha, N., Sianturi, L. T., \& Siagian, E. R. (2017). IMPLEMENTASI DATA MINING

PENJUALAN SABUN DENGAN MENGGUNAKAN METODE APRIORI ( Studi Kasus :

PT. Unilever). In Majalah Ilmiah INTI.

Al-Maolegi, M., \& Arkok, B. (2014). An improved Apriori algorithm for association rules. ArXiv Preprint ArXiv:1403.3948.

Azhari, A., \& Anshori, A. (2015). Pendekatan Aturan Asosiasi Untuk Analisis Pergerakan Saham. Seminar Nasional Informatika (SEMNASIF), 1(5).

Binsar, J., Pangaribuan, M., \& Ali, H. (2018). Influence Service Quality, Customer Relationship 
and Customer Satisfaction to Customer Loyalty: Case Study in Individual Customer PT. Prudential in 2016. Saudi Journal of Business and Management Studies (SJBMS. https://doi.org/10.21276/sjbms.2018.3.4.7

Joni Abdul Kasir. (2021). Kedai Kopi Milenial Menjamur di Padang, Gubernur Sumbar:

Kontribusi Positif. Klikpositif.Com.

https://www.ilovepdf.com/download/7kxdl0cfmz0hnrrn2h5ccyAqlyAc8jrjnrjbwm2ktv8hcwh 7qbjtk95vcm18hnch38ys5236gd3qA5b03cjrkj0pvp95z6nbxnq17djm8fcAlvppzgshbxc7w3d6 hc1fzxj0mzglgnnAAryc3q79ddAy0mz8mm4qmyn8qmvx0m27238wt4w1/49o

Hairiyah, S., \& Ali, H. (2017). Customer Decision Analysis in Taking Multipurpose Loan: Promotions, Locations and Credit Procedures ( A Case of the Bank " PQR Jakarta "). Saudi Journal of Business and Management Studies. https://doi.org/10.21276/sjbms.2017.2.3.6

Nofriansyah, D. (2014). Konsep Data Mining Vs Sistem Pendukung Keputusan - Dicky Nofriansyah, S.Kom., M.Kom. - Google Buku. In Deepublish.

Nofriansyah, D., \& Defit, S. (2017). Multi Criteria Decision Making (MCDM) pada Sistem Pendukung Keputusan. Deepublish.

Septiano, R. (2020). ANALISIS PEYUSUNAN STRATEGI BISNIS PADA RAYHAN TOKO MUSLIM. Jurnal Ilmu Manajemen Terapan, 1(4), 401-415.

Septiano, R., \& Sari, L. (2020). DETERMINATION OF CONSUMER LOYALTY THROUGH CUSTOMER SATISFACTION. Dinasti International Journal of Economics, Finance \& Accounting, 1(5), 865-878.

Siburian, B. R. (2014). Aplikasi Data Mining Untuk Menampilkan Tingkat Kelulusan Mahasiswa Dengan Algoritma Apriori. Pelita Informatika Budi Darma, 7(2), 56-61.

Sugiyono. (2017). MetodePenelitian Kuantitatif, Kualitatif dan R\&D. Bandung: PT Alfabet. In Sugiyono. (2017). MetodePenelitian Kuantitatif, Kualitatif dan R\&D. Bandung: PT Alfabet. https://doi.org/10.1017/CBO9781107415324.004

Sugiyono, D. (2019). Statistika untuk Penelitian (Cetakan ke-30). In Bandung: CV ALFABETA.

Tampubolon, K., Saragih, H., Reza, B., Epicentrum, K., \& Asosiasi, A. (2013). Implementasi Data Mining Algoritma Apriori pada sistem persediaan alat-alat kesehatan. Majalah Ilmiah Informasi Dan Teknologi Ilmiah, 1(1), 93-106.

Wanto, A., Siregar, M. N. H., Windarto, A. P., Hartama, D., Ginantra, N. L. W. S. R., Napitupulu, D., Negara, E. S., Lubis, M. R., Dewi, S. V., \& Prianto, C. (2020). Data Mining: Algoritma dan Implementasi. Yayasan Kita Menulis. 